\section{Studi Ayat Manajemen}

Al-Qur'an adalah kalamullah yang diturunkan kepada nabi Muhammad Saw dengan perantara malaikat Jibril sebagai mu'jizat. Al-Qur'an adalah sumber ilmu bagi kaum muslimin yang merupakan dasar-dasar hukum yang mencakup segala hal termasuk ilmu manajamen baik dalam pendidikan maupun bidang lain.

Manajemen dalam pendidikan sangat penting dan sangat mempengaruhi system pendidikan sebagai petunjuk arah dan penataan dari seluruh pengelolaan fungsi-fungsi yang ada pada suatu lembaga atau instansi islam yang melibatkan sumber daya manusia dalam menggerakkannya. Semua itu juga harus dilandasi oleh al-qur'an sebagai pedoman umat islam yang merupakan salah satu sumber ilmu manajemen dan dikaitkan dengan fungsi-fungsi manajemen dalam pendidikan.

Buku ini berisikan ayat-ayat manajemen yang ada dalam al-qur'an sebagai pedoman dan acuan dalam mengatur dan mengelola manajemen dalam pendidikan, salah satunya berupa konsep dasar dari al-qur'an, dasar pendidikan dalam alqur'an, manajemen pendidikan keluarga dan lain-lain.

Buku ini hanya karya kecil yang mencoba untuk berbagi ilmu kepada pembaca yang kiranya bisa menjadi referensi baik perorangan maupun instansi lembaga pendidikan islam. Buku ini sangat jauh dari kesempurnaan maka sangat diharapkan kritik dan saran dari berbagai pihak untuk penyempurnaan buku ini dimasa yang akan datang.

\section{ALISYAH PITRI, M.Pd \\ NILFATRI, S.E.I., M.H}

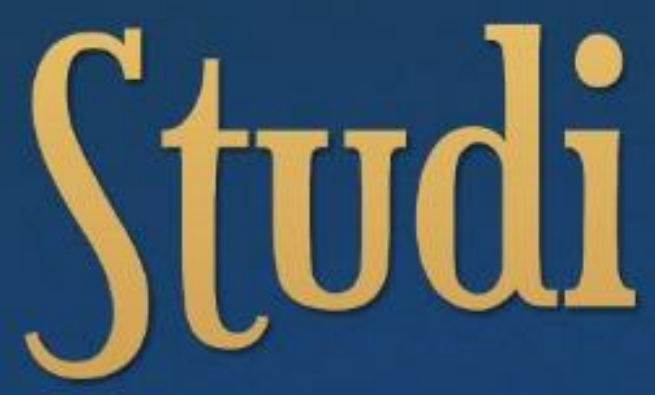

Ayat

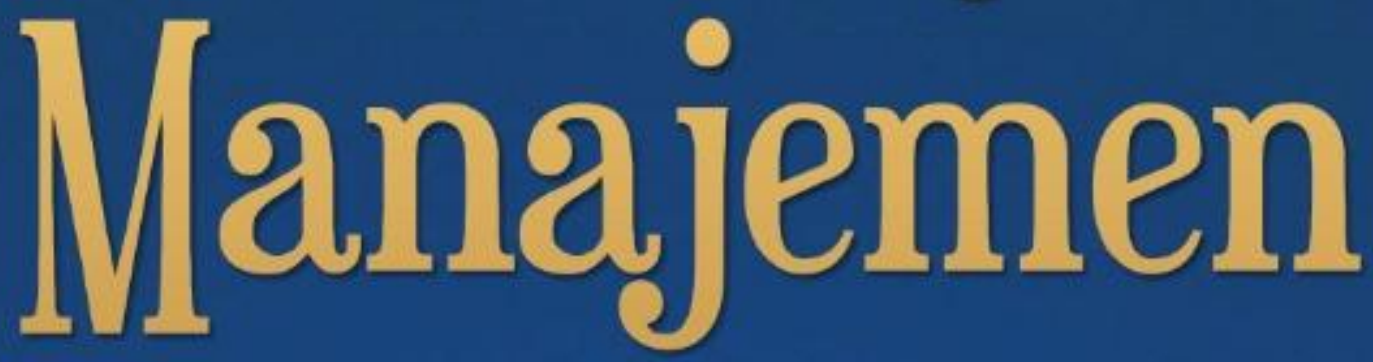

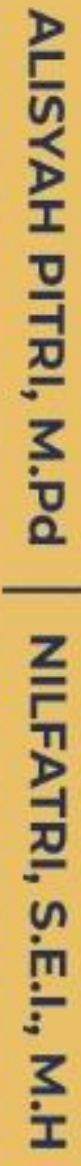

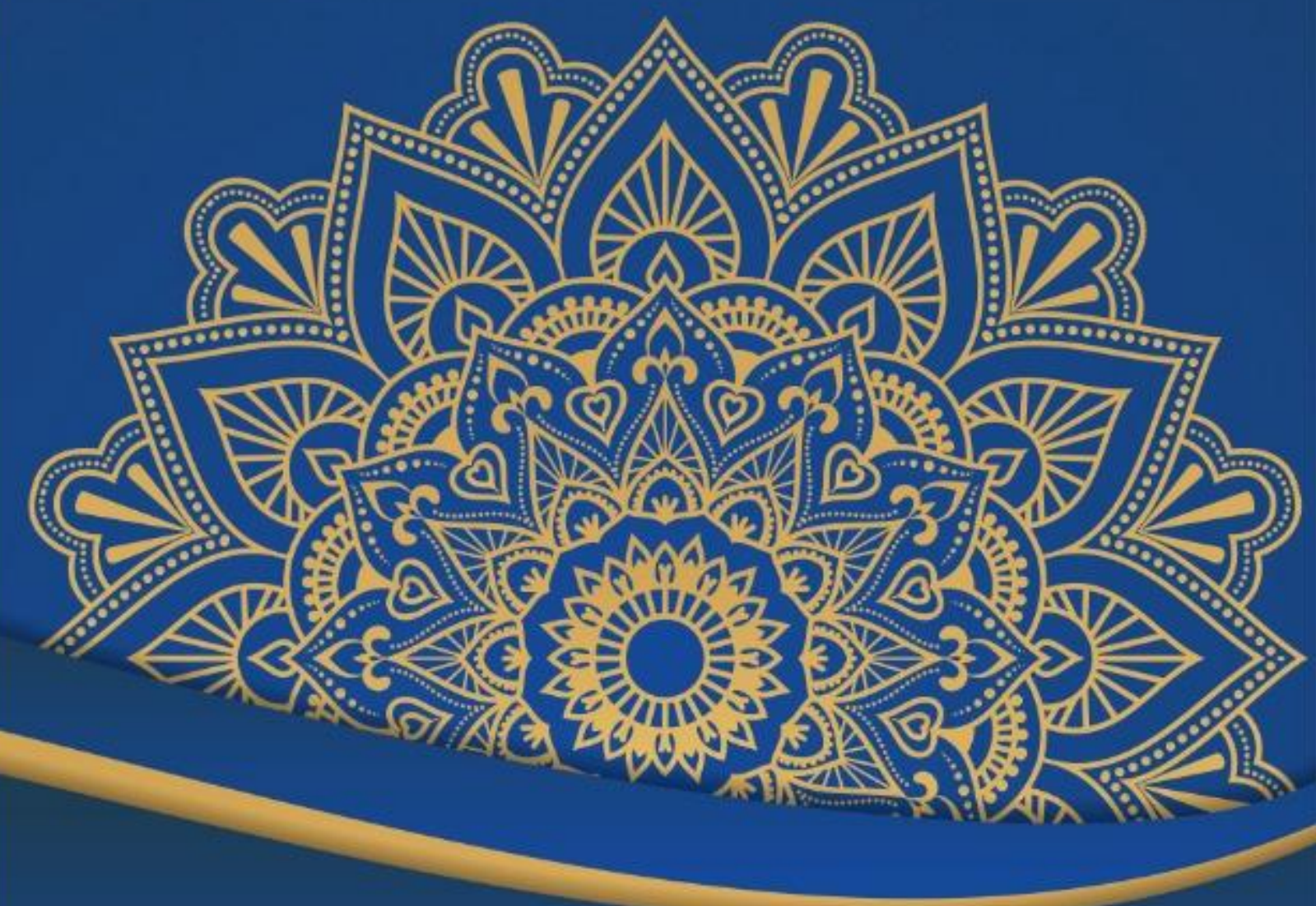




\section{STUDI AYAT MANAJEMEN}

Alisyah Pitri, M.Pd

Nilfatri, S.E.I., M.H

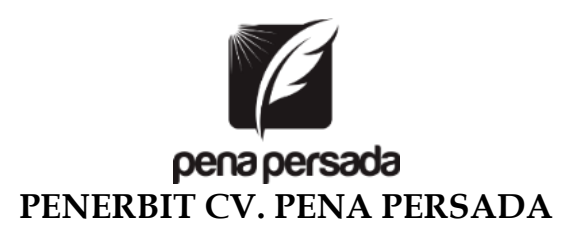




\section{STUDI AYAT MANAJEMEN}

Penulis:

Alisyah Pitri, M.Pd

Nilfatri, S.E.I., M.H

ISBN :

Design Cover :

Retnani Nur Briliant

\section{Layout :}

Nisa Falahia

\section{Penerbit CV. Pena Persada}

Redaksi :

Jl. Gerilya No. 292 Purwokerto Selatan, Kab. Banyumas

Jawa Tengah

Email : penerbit.penapersada@gmail.com

Website : penapersada.com Phone : (0281) 7771388

\section{Anggota IKAPI}

All right reserved

Cetakan pertama : 2021

Hak Cipta dilindungi oleh undang-undang. Dilarang memperbanyak karya tulis ini dalam bentuk apapun tanpa izin penerbit 


\section{KATA PENGANTAR}

Bismillahirrahmanirrahim

Assalamu'alaikum Warahmatullah Wabarakatuh

Puji syukur tim penulis ucapkan ke hadirat Allah SWT. atas rahmat, hidayah dan Ridho-Nya, tim penulis dapat menyelesaikan buku yang membahas studi ayat manajemen.

Tim penulis termotivasi menerbitkan buku ini karena untuk mewujudkan kewajiban tim penulis sebagai dosen agar menjadi bahan referensi bagi mahasiswa, akademisi, dan pemerintah yang tertarik dengan kajian yang dibahas penulis dan memberikan contoh kepada anak-anak kami untuk aktif menulis buku.

Tim penulis menyampaikan terimakasih dan penghargaan yang setinggi-tingginya kepada semua pihak, khususnya keluarga kami atas dukungannya baik berupa moril maupun materil dalam penyelesaian buku ini.

Muatan buku ini masih jauh dari kesempurnaan. Oleh sebab itu, tim penulis sangat mengharapkan saran dan kritikan yang konstruktif. Tim penulis mengharapkan pula kiranya buku ini dapat dimanfaatkan oleh kalangan yang membutuhkan.

Selanjutnya tim penulis menyampaikan pula terimkasih kepada pimpinan dan staf penerbit yang telah membantu menerbitkan buku ini.

Jambi, 25 Desember 2020

Tim penulis

Alisyah Pitri \& Nilfatri 


\section{DAFTAR ISI}

KATA PENGANTAR ................................................................iii

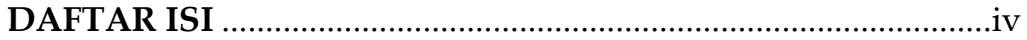

\section{CHAPTER 1:}

\section{ULUM AL-QUR'AN}

A. Pendahuluan ...................................................................... 1

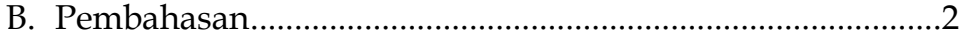

1. Pengertian Ulum Al-Qur'an .........................................2

2. Sejarah perkembangan Ulum al-Qur'an: Tokoh serta Karya-Karya Tentang Ulum al-Qur'an Hingga Sekarang..... .9

3. Urgensi dan Peranan Ulum al-Qur'an dalam Memahami/Menafsirkan al-Qur'an. 16

C. Penutup....................................................................................18

D. Daftar Pustaka ....................................................................19

\section{CHAPTER 2:}

PENGERTIAN AL-QUR'AN, NAMA-NAMA DAN SIFAT AL-QUR'AN

A. Pendahuluan .........................................................................20

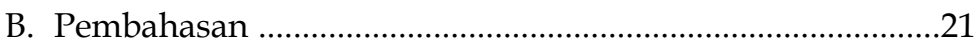

1. Pengertian Al-Qur'an, Nama-Nama dan Sifat Al-Qur'an .........................................................................21

a. Pegertian Al-qur'an..................................................21

b. Nama-nama Al-Quran.............................................21

c. Sifat-sifat Al-Quran ....................................................27

2. Fungsi Al-Qur'an Dan Kandungan Alqur'an ................28

a. Fungsi Al-Qur'an........................................................28

b. Kandungan Al-qur'an.................................................31

3. Perbedaan Al-Qur'an, Hadits Dan Hadits Qudsi...........34

4. Persamaan dan Perbedaan Al-Qur'an dengan Kitab Samawy Lainnya...........................................................35

5. Jaminan Allah Terhadap Kemurnian Al-Qur'an dan Bukti Otentisitas Al-Qur'an.............................................36

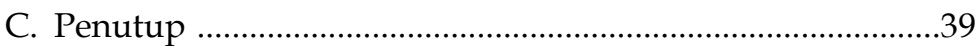

D. Daftar Pustaka ........................................................................41 


\section{CHAPTER 3:}

\section{I'JAZ AL-QUR'AN}

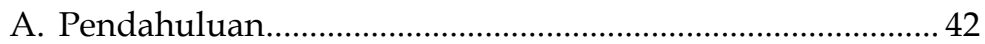

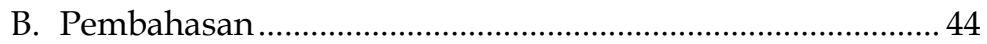

1. Pengertian I'Jaz Al-Qur'an................................................. 44

2. Segi-segi Kemukjizatan Al-qur'an dan Peranannya dalam Penyampaian Risalah ............................................ 48

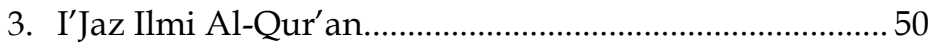

4. Bukti Historis Kegagalan Menandingi Al-Qur'an..........59

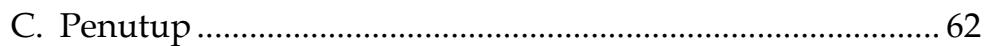

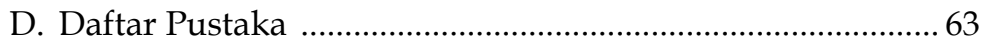

\section{CHAPTER 4:}

\section{PEMELIHARAAN AL-QUR'AN}

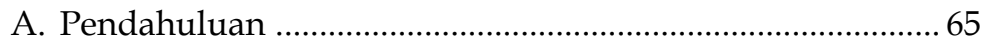

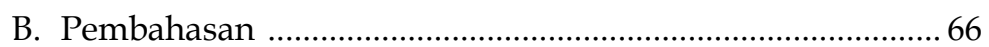

1. Pemeliharaan Al-Qur'an Pada Masa Nabi .......................66

2. Pemeliharaan Al-Qur'an Pada Masa Abu Bakar dan

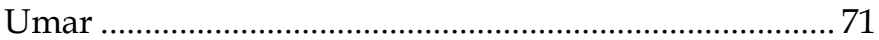

3. Kodifikasi Al-Qur'an pada Masa Utsman Bin Affan .... 75

4. Usaha Pemeliharaan Al-Qur'an setelah Khalifah yang

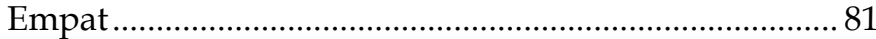

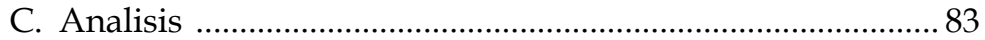

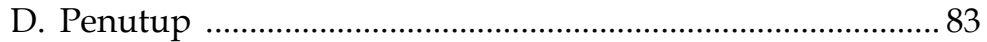

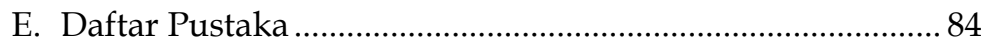

\section{CHAPTER 5:}

PENGERTIAN TAFSIR DAN ILMU TAFSIR, MUFASSIR

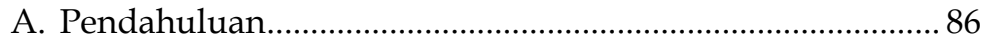

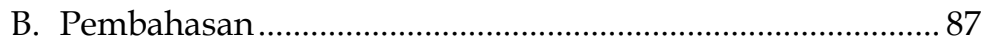

1. Pengertian tafsir, ilmu tafsir dan perbedaannya ............87 87

2. Perbedaan tafsir dan ilmu tafsir ........................................ 87

3. Pengertian ilmu tafsir ...................................................... 91

4. Perbedaan tafsir dan ilmu tafsir ....................................... 92

5. Pengertian mufassir dan syarat-syaratnya ...................... 92

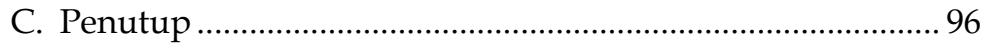

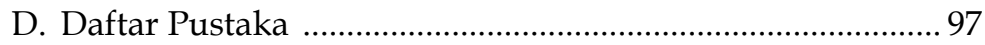




\section{CHAPTER 6:}

\section{TAFSIR, TAKWIL DAN TARJAMAH}

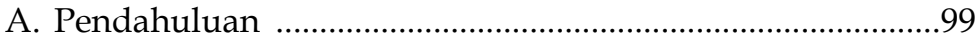

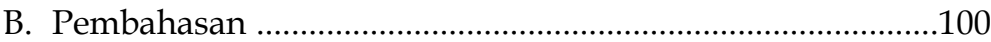

1. Pengertian Takwil, hukum takwil dan contohnya ..........100

2. Pengertian Tarjamah, klasifikasi, hukum dan contohnya.

3. Perbedaan prinsipil antara tarjamah, tafsir dan takwil.111

C. Analisis

D. Penutup

E. Daftar Pustaka

\section{CHAPTER 7:}

\section{METODOLOGI TAFSIR, YANG MELIPUTI: PENGERTIAN}

TAFSIR, TAFSIR TAHLILI, TAFSIR IJMALI, TAFSIR MUQARRAN, SUMBER-SUMBER TAFSIR
A. Pendahuluan .116
B. Pembahasan
1. Pengertian Tafsir
2. Macam-Macam Metode Tafsir
3. Sumber-Sumber Tafsir 123
C. Penutup .128
D. Daftar Pustaka 128

\section{CHAPTER 8:}

DASAR-DASAR PENDIDIKAN DALAM AL-QUR'AN

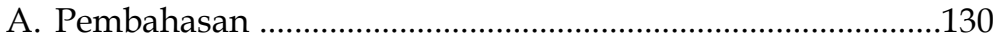

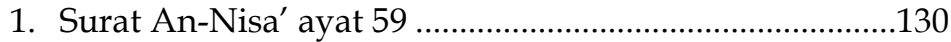

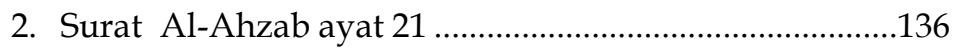

3. Surat Al-Hasyir ayat 7 ...................................................140

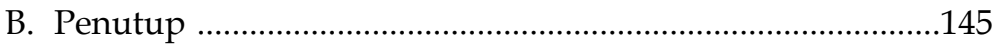

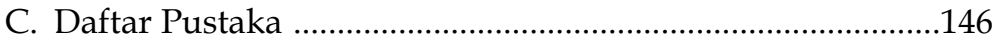

\section{CHAPTER 9:}

PENAFSIRAN AYAT-AYAT TENTANG TUJUAN

\section{PENDIDIKAN}

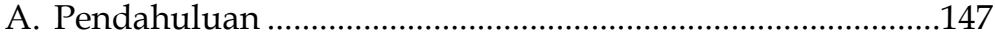

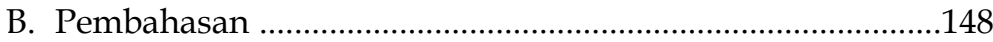

1. Pengertian Tujuan Pendidikan ......................................148

2. Penafsiran Ayat- Ayat Tentang Tujuan Pendidikan......149 
3. Tujuan Pendidikan dari Berbagai Perspektif 161

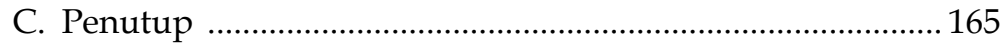

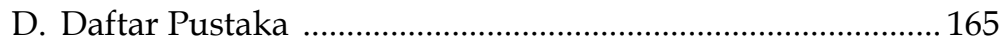

\section{CHAPTER 10 :}

MANAJEMEN PENDIDIKAN KELUARGA

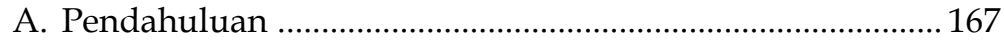

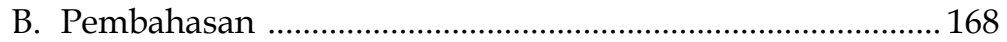

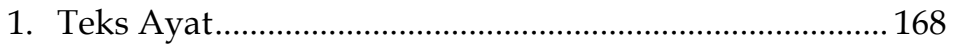

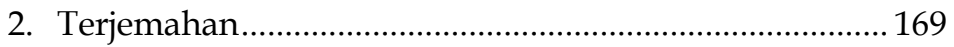

3. Tafsir Ayat Menurut Ahli Tafsir ...................................... 170

4. Penafsiran Ayat Menurut Pendekatan Manjemen ........ 176

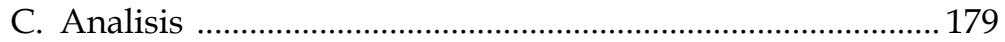

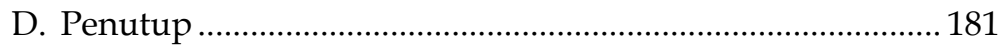

E. Daftar Pustaka ......................................................................... 182

\section{CHAPTER 11 :}

\section{MANAJEMEN AKIDAH}

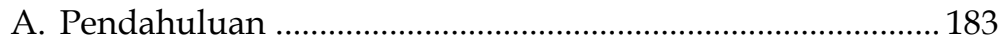

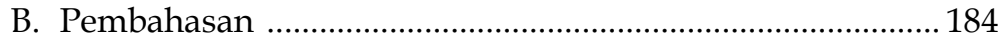

1. Makna akidah dan perbedaannya dengan istilah lain yang sejenis ............................................................... 184

2. Ruang lingkup akidah ................................................... 187

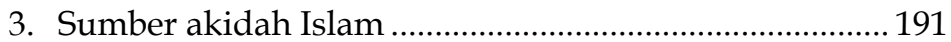

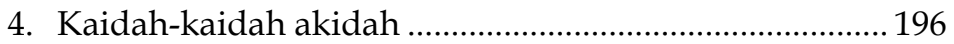

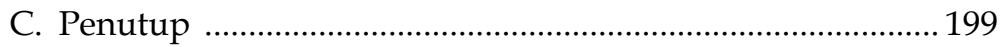

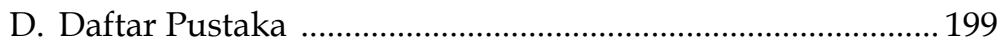

CHAPTER 12:

MANAJEMEN PENDIDIKAN IBADAH DALAM ALQUR'AN

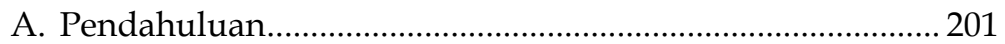

B. Ayat-ayat tentang Pendidikan Ibadah .................................. 201

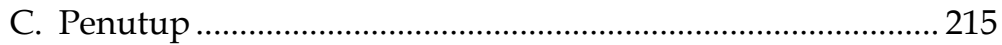

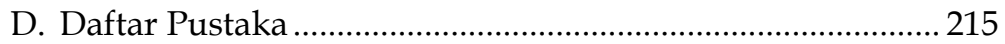

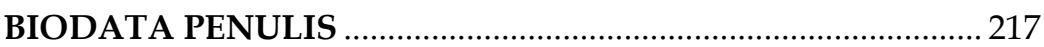


STUDI AYAT MANAJEMEN 


\section{CHAPTER 1: ULUM AL-QUR'AN}

\section{A. Pendahuluan}

Dalam pembahasan makalah ini, marilah kita mengenal lebih jauh mengenai Ulumul Qur'an. Al-Qur'an adalah kalamullah yang diturunkan kepada nabi Muhammad Saw dengan perantara malaikat Jibril sebagai mu'jizat. Al-Qur'an adalah sumber ilmu bagi kaum muslimin yang merupakan dasar-dasar hukum yang mencakup segala hal.

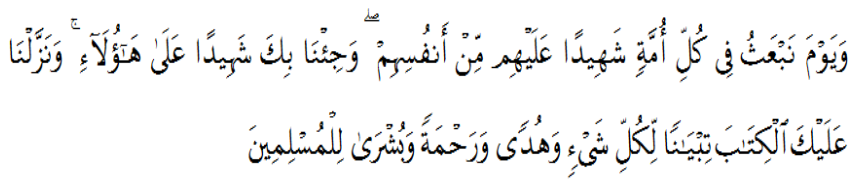

Artinya: "Kami turunkan kepadamu Al-Kitab untuk menjelaskan segala sesuatu dan petunjuk serta rahmat dan kabar gembira bagi orang-orang yang berserah diri." (An-Nahl : 89).

Mempelajari isi al-Qur'an akan menambah perbendaharaan baru, memperluas pandangan dan pengetahuan, meningkatkan perspektif baru dan selalu menemui hal-hal yang selalu baru. Lebih jauh lagi, kita akan lebih yakin akan keunikan isinya yang menunjukkan Maha Besarnya Allah sebagai penciptanya.

Al-Qur'an diturunkan dalam bahasa Arab. Oleh karena itu, ada anggapan bahwa setiap orang yang mengerti bahasa Arab dapat mengerti isi al-Qur'an. Lebih dari itu, ada orang yang merasa telah dapat memahami dan menafsirkan al-Qur'an dengan bantuan terjemahnya, sekalipun tidak mengerti bahasa Arab. Padahal orang Arab sendiri banyak yang tidak mengerti kandungan al-Qur'an. Maka dari itu, untuk dapat mengetahui isi kandungan al-Qur'an diperlukanlah ilmu yang mempelajari 
bagaimana tata cara menafsiri al-Qur'an yaitu Ulumul Qur'an dan juga terdapat faedah-faedahnya. Dengan adanya pembahasan ini, kita sebagai generasi islam supaya lebih mengenal al-Qur'an, karena tak kenal maka tak sayang.

Ulum Al-Qur'an merupakan ilmu yang mencakup pembahasan-pembahasan yang berhubungan al-Qur'an. Fungsi utama dari al-Qur'an adalah sebagai petunjuk dan sumber hidayah bagi kita umat islam.

Al Qur'an adalah al-nur, wahyu Allah yang diturunkan kepada nabi Muhamad Saw sebagai undang-undang yang adil dan syari'at yang kekal, sebagai pelita bersinar terang dan petunjuk yang nyata. Di dalamnya termuat berita tentang umat masa lampau dan umat masa mendatang; di dalamnya terdapat hukum-hukum yang mengatur kehidupan manusia. Tujuan untuk mempelajari ulum Qur'an untuk memperdalami ilmu al-Qur'an dan mudah memahami menafsirkan al-Qur'an secara benar.

\section{B. Pembahasan}

\section{Pengertian Ulum Al-Qur'an}

\section{a. Pengertian Ilmu dan Ulum Secara Bahasa (Arab)}

Ulum Al-Qur'an berasal dari bahasa Arab yang terdiri dari dua kata, yaitu "ulum" dan al-Qur'an. Kata "ulum" merupakan bentuk jamak dari kata "ilmu". Ilmu berarti paham dan menguasai. Kata ilmu semakna dengan (معرفة) yang berarti (pengetahuan), sedangkan Ulum berarti sejumlah pengetahuan dan al-Qur'an, sebagaimana didefinisikan ulama ushul, ulama fiqih dan ulama bahasa, adalah "kalam Allah yang diturunkan kepada Nabinya, Muhammad, yang lafazh-lafazhnya mengandung mukjizat, membacanya mempunyai nilai ibadah, yang diturunkan secara mutawir, dan yang tulis pada mushaf, mulai dari awal surat al-Fatihah sampai akhir surat an-Nas".1

\footnotetext{
${ }^{1}$ Rosihin Anwar, Ulum Al-Qur'an, (Bandung: CV Pustaka Setia, 2010), h. 11
} 
Definisi 'Ulum Qur'an menurut para ulama, sebagai berikut:

1) Menurut As-Suyuthi dalam kitab Itmamud Dirayah, Ulum Qur'an yaitu suatu ilmu yang membahas tentang keadaan al-Qur'an dari segi turunnya, sanad, adabnya, makna-maknanya baik yang berhubungan dengan lafazh-lafazhnya maupun yang berhubungan dengan hukum-hukumnya dan sebagainya.

2) Menurut al-Zarqani, 'Ulum Qur'an yaitu beberapa pembahasan masalah yang berhubungan dengan alQur'an dari segi turun, urutan-urutan, pengumpulan, penulisan, pembacaan, mu'jizat, nasikh dan mansukhnya, dan penolakkan/bantahan terhadap hal-hal yang bisa menimbulkan keragu-raguan (confused) terhadap al-Qur'an (yang sengaja dilancarkan oleh kaum orientalis dan atheis dengan maksud untuk menodai kesucian al-Qur'an) dan sebagainya. $^{2}$

3) Menurut Asy-Syaikh Al-Maghraby, 'Ulum Qur'an yaitu suatu ilmu yang menjelaskan sesuatu keadaan dari keadaan-keadaan al-Qur'an, baik mengenai penafsiran ayat-ayatnya, mengenai pena'wilan ayatayatnya, mengenai penjelasan maksud-maksudnya, mengenai sebab-sebab nuzulnya, mengenai nasikh dan mansukhnya, mengenai persesuaian sesuatu ayat dengan yang sebelumnya dan sesudahnya, mengenai uslub-uslubnya, mengenai rupa-rupa qiraatnya, mengenai cara meresapkan kalimat-kalimat dan lainlain yang berhubungan dengan itu. ${ }^{3}$

2 Said Agil Husin Al-Munawar, Al-Qur'an Pengembangan Tradisi Kesalehan Hakiki, (Jakarta: PT.Ciputat Press, 2005), h. 6

${ }^{3}$ Mashuri Sirojuddin Iqbal, Pengantar Ilmu Tafsir,( Bandung: Angkasa, 2005), h.121 
Dari definisi di atas dapat kita simpulkan bahwa 'Ulum Qur'an adalah merupakan suatu ilmu yang lengkap serta mencakup segala ilmu yang berhubungan dengan al-Qur'an, baik berupa ilmu-ilmu agama seperti tafsir, ataupun berupa ilmu-ilmu bahasa Arab seperti ilmu i'rabil Qur'an.

b. Pengertian Ilmu dan Ulum secara Istilah ketika Dipakai pada Istilah Ulum, bukan Ilmu al-Qur'an

Kata "Ulum" didasarkan kepada kata al-Qur'an telah memberikan pengertian bahwa ilmu merupakan kumpulan sejumlah ilmu yang berhubungan dengan AlQur'an, baik dari segi keberadaannya sebagai al-Qur'an maupun dari segi pemahamannya terhadap petunjuk yang terkandung di dalamnya. ${ }^{4}$

Menurut para ulama definisi ilmu dan ulum adalah sebagai berikut:

1) Menurut para ahli filsafat, kata ilmu sebagai gambaran sesuatu yang terdapat dalam akal.

2) Menurut Abu Musa Al-Asy'ari, ilmu ialah sifat yang mewajibkan pemiliknya mampu membedakan dengan panca indranya.

3) Menurut Imam Ghazali, secara umum arti ilmu dalam istilah syara' adalah ma'rifat Allah terhadap tanda-tanda kekuasaan, perbuatan, hamba-hamba dan makhluk-Nya.

4) Menurut Muhammad Abdul 'Adzhim, ilmu menurut istilah adalah ma'lumat-ma'lumat yang dirumuskan dalam satu kesatuan judul atau tujuan. ${ }^{5}$

Dari beberapa pengertian di atas, dapat disimpulkan bahwa kata "ulum/ilmu" adalah masalahmasalah yang telah dirumuskan dalam satu disiplin pengetahuan yang terdapat dalam akal.

${ }^{4}$ Ahmad Sadali, Ulumul Qur'an I, (Bandung: Pustaka Setia, 2006), h.11

h. 2

${ }^{5}$ Chaerudji Abd Chalik, 'Ulum Al-Qur'an, (Jakarta:Media Peustaka, 2013), 


\section{c. Ruang Lingkup Ulum al-Qur'an/Cabang-cabang/ Pembahasan Ulum Qur'an}

'Ulum al-Qur'an mempunyai ruang lingkup pembahasan yang luas, meliputi semua ilmu yang ada hubungannya dengan al-Qur'an, baik berupa ilmu-ilmu agama, seperti tafsir maupun ilmu-ilmu bahasa Arab, seperti ilmu Balaghah dan I'arab al-Qur'an.

Menurut Ramli Wahid sebagian ilmu ini masih dapat dipecah kepada beberapa cabang dan macam ilmu yang masing-masing mempunyai obyek kajian tersendiri. Setiap obyek dari ilmu-ilmu ini menjadi ruang lingkup pembahasan 'Ulum al-Qur'an.

Kajian 'Ulum al-Qur'an ini demikian luasnya, sehingga sebagian ulama menganggapnya tak terbatas. al-Sayuthi memperluasnya sehingga memasukkan astronomi, ilmu Ukur dan sebagainya ke dalam kajian 'Ulum al-Qur'an.

'Ulum al-Qur'an meliputi jumlah 77.450 ilmu. Hal itu menurut perhitungan jumlah kalimat yang ada dalam al-Qur'an meliputi dikalikan empat, karena setiap kalimat mengandung makna zhahir, batin, terbatas dan tak terbatas. Itu dilihat dari segi jumlah mufdaratnya, namun jika dilihat dari sudut kaitan-kaitan susunan kalimat, maka bilangan 'Ulum al-Qur'an tak terhingga. Hanya Allah yang mengetahui jumlahnya".

'Ulum al-Qur'an berbeda dengan suatu ilmu yang merupakan cabang dari padanya, misalnya Ilmu Ilmu tafsir yang menitik beratkan pembahasannya pada penafsiran ayat-ayat al-Qur'an. Karena ilmu ini diberi nama 'Ulum al-Qur'an dengan majemukm bukan ilmu al-Qur'an dengan bentuk mufrad.

Menurut Hasbi As Shiddieqy yang agaknya mengutip dari Manahil al-Irfan karya al-Zarqani memandang bahwa segala macam pembahasan 'Ulumul al-Qur'an itu kembali kepada beberapa pokok persoalan saja, yaitu: 
Pertama, persolalan tempat turunnya ayat, waktunya dan peristiwanya. Hal ini terdiri dari dua belas macam. Yaitu, al-Makkiy (ayat-ayat yang turun di Mekkah), al-Madaniy (ayat-ayat yang turun di Madinah), al-Safariy (ayat-ayat yang turun ketika nabi dalam perjalanan), al-Hadhiriy (ayat-ayat yang turun ketika nabi berada di rumah), al-Lailiy (ayat-ayat yang turun pada malam hari), al-Nahariy (ayat-ayat yang turun pada siang hari), al-Shaifiy (ayat-ayat yang turun ketika musim panas), Syita-i (ayat-ayat yang turun ketika musim dingin), al-Firasyi (ayat-ayat yang turun ketika nabi berada di tempat tidur), Asbab al-Nuzul (sebab-sebab turun ayat), Awwalu ma Nuzzila (ayat-ayat yang mulamula turun), akhiru ma Nuzzila (ayat-ayat yang terakhir turun).

Kedua, persoalan sanad al-Qur'an, terdiri dari enam macam, yaitu sanad mutawatir, ahad, syadz, Qiraat al-nabi (bnetuk-bentuk Qiraat Nabi SAW), alRuwat (para periwayat), al-Huffazh (para penghapal alQur'an).

Ketiga, persoalan Ada' al-Qiraah (tentang cara membaca al-Qur'an), ini terdiri dari enam macam pula, yaitu, waqaf (cara berhenti), ibtida (cara memulai), imalah, madd (bacaan yang dipanjangkan), takhfif alHamzah (meringankan bacaan hamzah), idgham (memasukkan bunyi huruf yang mati kepada bunyi huruf sesudahnya).

Keempat, persoalan yang menyangkut lafazh-lafazh al-Qur'an, dan ini ada tujuh macam yaitu lafazh gharib (pelik), mu'rab (menerima perubahan akhir kata), majaz (metafora), musytarak (lafazh yang mengandung lebih dari satu makna), mutaradif (sinonim), isti'arah (asosiasi dan tasybih (penyerupaan).

Kelima, persoalan tentang makna-makna al-Qur'an yang berhubungan dengan hukum, dan ini ada empat belas macam, yaitu, al-Am al-Baqi'ala 'ala 'umumihi (lafazh 
yang bermakna 'am (umum) dan tetap dalam keumumannya), al-'am al-makhshus (lafazh am yang khusus), al-'am alladzi uridu bihi al-khusus (lafazh yang bermakna umum tapi yang dimaksudkan khusus), ma khashshasa fihi al-Kitabu al-Sunnata (lafazh am (umum) yang dikhususkan oleh al-Kitab terhadap Sunnah), makhashshashat fihi al-Sunnatu al-Kitaba (lafazh am (umum) yang dikhususkan oleh Sunnah terhadap Kitab), mujmal (global), mubayyan (penjelasan), muawwal (dita'wil), mafhum (pemahaman), muthlaq (tidak terbatas), muqayyad (terbatas), nasikh (menghapus), mansukh (dihapus), nau'min al-nasikh wa al-mansukh wahuwa ma amila bihi muddatan mu'ayyanatan, wal amila bihi wahidun min al-mukallafina (semacam nasikh dan mansukh, yaitu yang diamalkan pada waktu tertentu dan yang diamalkan oleh seorang saja dari orang-orang mukallaf).

Keemam, persoalan makna al-Qur'an yang berhubungan dengan lafazh, dan ini ada lima macam, yaitu, al-Fashl (pisah), al-Washl (nyambung), Ijaz (singkat), Ithnab (panjang), dan Qashr (pendek).

Dari keterangan di atas dapat kita simpulkan bahwa pada dasarnya ruang lingkup atau pokok pembahasan 'Ulum al-Qur'an adalah ilmu-ilmu Agama dan bahasa Arab. Namun mengingat kenyataan adanya ayat-ayat yang menyangkut berbagai disiplin ilmu pengetahuan sekuler, maka untuk menafsirkannya memerlukan pengetahuan dari masing-masing disiplin ilmu tersebut.dengan demikian dijelaskan bahwa ilmu pengetahuan umum termasuk bagian dari 'Ulum alQur'an menurut al-Sayuthi.

Menurut Hasbi Ash-Shiddieqy ada tujuh belas cabang-cabang (pokok bahasan) 'Ulum Al-Qur'an adalah sebagai berikut:

1) Ilmu Adab Tilawat al-Qur'an, yaitu ilmu-ilmu yang menerangkan aturan-aturan (etika) dalam pembacaan Al-Qur'an. 
2) Ilmu Tajwid, yaitu ilmu yang menerangkan cara-cara membaca Al-Qur'an, tempat memulai, atau tempat berhenti (waqaf).

3) Ilmu Mawathin an-Nuzul, yaitu ilmu yang menerangkan tempat-tempat, musim, awal, dan akhir turun ayat.

4) Ilmu Tawarikh an-Nuzul, yaitu ilmu yang menerangkan dan masa dan urutan turun ayat, satu demi satu dari awal hingga akhir turunnya.

5) Ilmu Asbab an-Nuzul, yaitu ilmu yang menerangkan sebab-sebab turun ayat.

6) Ilmu Qira'at, yaitu ilmu yang menerangkan ragam qira'at (pembacaan Al-Quran) yang telah diterima Rasulullah SAW. Qira'at ini apabila ini apabila dikumpulkan terdiri atas sepuluh macam, ada yang sahih dan ada pula yang tidak sahih.

7) Ilmu Gharib al-Qur'an, yaitu ilmu yang menerangkan makna kata-kata yang ganjil yang tidak terdapat dalam kitab-kitab kovensional, atau tidak terdapat dalam percakapan sehari-hari. Ilmu ini menerangkan kata-kata yang halus, tinggi, dan petik.

8) Ilmu I'rab al-Qur'an, yaitu ilmu yang menerangkan harakat al-Qur'an dan kedudukan sebuah kata dalam kalimat.

9) Ilmu Wujud wa an-Nazhar'ir, yaitu ilmu yang menerangkan kata-kata Al-Qur'an yang mempunyai makna lebih dari satu.

10) Ilmu Ma'rifat al-Muhkam wa al-Mutasyabih, yaitu ilmu yang menerangkan ayat-ayat yang dipandang muhkam dan yang dipandang mutasyabih.

11) Ilmu Nasikh wa al-Mansukh, yaitu ilmu yang menerangkan ayat-ayat yang mansukh oleh sebagian mufassir.

12) Ilmu Badai'u al-Qur'an, yaitu ilmu yang menerangkan keindahan susunan bahasa al-Qur'an. 
13) Ilmu I'jaz al-Qur'an, yaitu ilmu yang menerangkan segi-segi kekuatan al-Quran sehingga dipandang sebagai suatu mukjizat dan dapat melemahkan penantang-penantangnya.

14) Ilmu Tanasub Ayat al-Quran, yaitu ilmu yang menerangkan persesuaian antara suatu ayat dengan ayat sebelum dan sesudahnya.

15) Ilmu Aqsam al-Quran, yaitu ilmu yang menerangkan arti dan maksud-maksud sumpah Allah yang terdapat di dalam al-Quran.

16) Ilmu Amtsal al-Qur'an, yaitu ilmu yang menerangkan perumpamaan-perumpamaan al-Quran, yakni menerangkan ayat-ayat perumpamaan yang dikemukakan al-Quran.

17) Ilmu Jadal al-Quran, yaitu ilmu yang menerangkan macam-macam perdebatan yang telah dihadapkan alQuran kepada segenap kaum musyrikin dan kelompok lainnya. ${ }^{6}$

Dari penjelasan di atas dapat kita simpulkan bahwa cabang-cabang pokok bahasan 'Ulum Al-Qur'an yang harus kita dikuasai dan kita fahami dalam mempelajari ilmu al-Qur'an yang lebih luas, sehingga kita bisa menafsirkan atau menterjemahkan al-Qur'an dan mendalami ilmu al-Qur'an yang benar.

2. Sejarah perkembangan Ulum al-Qur'an: Tokoh serta Karya-Karya Tentang Ulum al-Qur'an Hingga Sekarang

\section{a. Sejarah Perkembangan Ulum al-Qur'an}

Sebagai ilmu pengetahuan berdiri sendiri, ulum alQur'an tidak lahir sekaligus, melainkan melalui proses pertumbuhan dan perkembangan. Istilah ini baru muncul pada abad ke-3 $\mathrm{H}$, sebagian ulama berpendapat, istilah ini lahir sebagai ilmu yang berdiri pada abad ke-5 
H. Karena Ulum al-Qur'an, baru muncul dalam karya Ali bin Ibrahim al-Hufi (w. $340 \mathrm{H}$ ), yang berjudul al-Burhan al-Qur'an.

Pada masa Rasulullah Saw. Samapi masa khalifah Abu Bakar (12 H- 13 H) dan Umar (13 H- 23 H), ilmu alQur'an masih di riwayatkan secara lisan. Ketika zaman kekhalifahan Utsman $(23 \mathrm{H}-34 \mathrm{H})$ di mana orang Arab mulai berguru dengan orang-orang non Arab, pada saat itu Utsman memerintahkan supaya kaum muslimin berpegang pada mushaf induk, dan membakar mushaf lainnya. Usaha yang dilakukan oleh Utsman dalam mereproduksi naskah al-Qur'an, berarti beliau telah meletakkan dasar ilm rasm al-Qur'an.

Masa kekhalifahan Ali bin Abi Thalib, $(35 \mathrm{H}-40 \mathrm{H})$ telah diperintahkan Abu al-Aswad al-Dauli (w. $69 \mathrm{H}$ ) untuk meletakkan kaedah-kaedah bahasa Arab. Usaha yang dilakukan Ali tersebut, dipandang sebagai peletakan dasar ilmu i'rab al-Qur'an.

Adapun tokoh-tokoh yang berjasa dalam menyebarkan ulum a-Qur'an melalui periwayatan adalah:

1) Khulafa al-Rasyidin, Ibn Abbas, Ibn Mas'ud, Zaib bin Tsabit, Ubai bin Ka'ab, Abu Musa al-Asy'ariy, dan Abdullah bin Zubair, dan Zaib bin Aslam. Mereka itu dari golongan sahabat.

2) Mujahid, 'Ata', Ikrimah, Qatadah, Hasan Basri, Sa'id bin Jubair, dan Zaid bin Aslam. Mereka dari golongan tabi' in di Madinah.

3) Malik bin Anas, dari golongan tabi'in, ia memperoleh ilmunya dari Zaid bin Aslam.

Tokoh-tokoh ini dianggap orang-orang yang meletakkan dasar ilmu tafsir, ilmu asbab al-Nuzul, ilmu nasikh dan mansukh, dan ilmu gharib al-Qur'an. 


\section{1) Perkembangan 'Ulum al-Qur'an Abad II H}

Pada abad II H, upaya pembukuan ulum alQur'an mulai dilakukan, namun pada masa ini perhatian ulama lebih banyak terfokus pada tafsir. Di antara ulama tafsir pada masa ini adalah:

a) Sufyan Ats-Tsauri (w. $161 \mathrm{H}$ )

b) Sufyan bin 'Uyainah (w. $198 \mathrm{H}$ )

c) Waqi' bin Al-Jarrh (128-197 H)

d) Syu'bah Al-Hajjaj (w. $160 \mathrm{H}$ )

e) Muqatil bin Sulaiman (w. $150 \mathrm{H})$

f) Ibn Jarir Ath-Thabari (w. $310 \mathrm{H}$ ). Tafsir yang ditulisnya, yakni Jami', penulisannya adalah orang yang pertama kali menyajikan tafsir dengan mengemukakan berbagai pendapat yang disertai pula dan proses tarjih. Kitab ini dipandang sebagai kitab yang pertama kali memcampuradukkan antara tafsir bi al-ma'tsur dengan tafsir bi ar-ra'yi.

\section{2) Perkembangan 'Ulum al-Qur'an Abad III H}

Pada abad III H, muncul Muhammad bin Jarir al-Tabari (w. $310 \mathrm{H}$ ) yang menyusun kitab tafsir yang bermutu karena banyak memeuat hadis-hadis shahih, ditulis dengan rumusan yang baik. Di samping itu memuat i'arab dan kajian-kajian pendapat. Pada masa ini telah disusun beberapa ulum al-Qur'an yang masing-masing berdiri sendiri, anatara lain:

a) Ali bin al-Madini (w. $234 \mathrm{H}$ ), gurunya Imam AlBukhari, menyusun kitab tentang ilmu Asbab AnNuzul.

b) Abu Ubaid Al-Qasimi bin salam (w. $224 \mathrm{H}$ ) yang menyusun ilmu nasikh wa Al-Mansukh, ilmu Qira'at, dan Fadha'il Al-Qur'an.

c) Muhammad bin Ayyub Adh-Dhurraits (w.294 H). Yang menyusun Ilmu Makki wa Al-Madani.

d) Muhammad bin Khalaf Al-Marzuban (w. 309 H) yang menyusun kitab Al-Hawi fi ‘Ulum Al-Quran. 